Portland State University

PDXScholar

Engineering and Technology Management

Faculty Publications and Presentations

3-1-2013

\title{
Fast and Frugal Heuristics for New Product Screening - Is Managerial Judgment "Good Enough?"
}

Antonie J. Jetter

Portland State University, ajetter@pdx.edu

Fatima M. Albar

Portland State University

Follow this and additional works at: https://pdxscholar.library.pdx.edu/etm_fac

Part of the Engineering Commons

Let us know how access to this document benefits you.

\section{Citation Details}

Jetter, Antonie J. and Albar, Fatima M., "Fast and Frugal Heuristics for New Product Screening - Is Managerial Judgment "Good Enough?"' (2013). Engineering and Technology Management Faculty Publications and Presentations. 25.

https://pdxscholar.library.pdx.edu/etm_fac/25

This Post-Print is brought to you for free and open access. It has been accepted for inclusion in Engineering and Technology Management Faculty Publications and Presentations by an authorized administrator of PDXScholar. Please contact us if we can make this document more accessible: pdxscholar@pdx.edu. 


\section{Fast and Frugal Heuristics for New Product Screening -is managerial judgment "good enough?"}

Fatima M. Albar

Department of Engineering and Technology Management, Portland State University, Portland, OR 972070751 USA and Faculty of Computing and Information Technology, King Abdul-Aaziz University, Jeddah, 22254

Saudi Arabia

Email: albarfm@pdx.edu

Antonie J. Jetter*

Department of Engineering and Technology Management, Portland State University, Portland, OR 97207-

0751 USA

E-mail: jettera@cecs.pdx.edu

*Corresponding author

Project screening in the fuzzy front-end of product development is dominantly based on managerial judgment, yet little is known about the quality of heuristic screening decisions. This research models three commonly discussed Fast and frugal (F\&F) heuristics for project screening (Take-the-Best, Tallying, and Elimination-by-Aspect) and explores their performance. An illustrative dataset of 52 new product development projects is used to compare the performance of $F \& F$ heuristics against that of regression models, which reflect compensatory judgment behaviour. The findings uncover a "less is more" effect that justifies the use of simple heuristics in early stage product screening; Two out of the three F\&F heuristics reach accuracies of over $80 \%$ for project selection and $70 \%$ for project rejection and the best F\&F model, Tallying, performs similarly to the best regression model. The findings warrant a fresh look at managerial screening heuristics as "good enough" decision making approach.

Keywords: project selection; project screening; fuzzy front-end; product development, heuristics, fast and frugal heuristics, take the best, tallying, elimination by aspect; decision making

Reference to this paper should be made as follows: Albar, F.M. and Jetter, A.J. (2013) 'Fast and frugal heuristics for new product screening - is managerial judgment 'good enough?", Int. J. Management and Decision Making, Vol. 12, No. 2, pp.165-189

\section{Biographical Information:}

Fatima M. Albar is a PhD candidate in Engineering and Technology Management at Portland State University. She holds a Masters in Software Engineering from Oregon Graduate Institute at Oregon Health and Science University. She has worked as a faculty member in the Department of Computer Science, Faculty of Computing and Information Technology, at King Abdul Aziz University, Jeddah, Saudi Arabia. In her doctoral research, she investigates managers' decision heuristics for complex decisions like screening projects at the fuzzy front end of new product development.

Antonie J. Jetter is an Assistant Professor in Engineering and Technology Management at Portland State University. She holds a Doctorate in Technology and Innovation Management from RWTH Aachen Technical University and has a total of eight years of work experience in high-tech companies. Her research aims to improve problem framing and decision making in the early stages of new product development and other 'wicked' decision environments. She has published three books and multiple journal and conference articles.

This paper is a revised and expanded version of a paper entitled An Investigation on Fast and Frugal Models for New Project Screening presented at PICMET, Portland, Oregon July 31 - August 4, 2011 


\section{Introduction}

The early stages of new product development, the so-called fuzzy front end (FFE) -(Smith \& Reinertsen, 1991; Koen, Ajamian, \& Boyce, 2002) encompass planning and evaluation activities that cumulate in the Go-/No-Go decision to either abandon a product idea or to accept it and start product development. Research suggests that improving decision-making in the screening phase can significantly increase project success rates (van Riel, Semeijn, Hammedi, \& Henseler, 2011). To support project screening in the FFE, the literature proposes methods that are grounded in rational decision theory, such as scoring models (Montoya-Weiss \& O'Driscoll, 2000) and analytical hierarchy process (AHP) (Calantone, diBenedetto, \& Schmidt, 1999). In practice, however, most decisions are made ad-hoc and based on managerial knowledge and previous experiences, rather than on analytical approaches (van Riel et al., 2011) because managers are not familiar with more sophisticated processes, find them computationally too demanding (Lockett, 1986), or do not have access to the type of input data that is required for advanced decision models (Sauter, 1999; Smith, 2003 ). Moreover, analytical decision approaches may be too static to be practical in dynamic environments that require that decision criteria are frequently adjusted to the changing realties of each project under scrutiny (Hammedi, van Riel, \& Sasovova, 2011). As a result, heuristics are used to determine if an idea finds a sponsor who is willing to take at least some minimal action, such as performing simple experiments, getting some early user input, and - most importantly - communicating and advocating the idea so that it becomes part of the company's idea pool (Cooper, 1985; Alam, 2003). Sponsors thus act as a "filtering mechanism" (Daellenbach, McCarthy, \& Schoenecker, 1999). The process is highly selective: by some estimates, it takes as much as 3000 raw ideas to have 300 ideas in the front-end idea pool (Stevens \& Burley, 1997). And of the 300 ideas that make it into the idea pool, approx. 50\% are abandoned before any analytical project selection methods, such as a business analysis, are being employed (own calculation, based on (Griffin, 1997)).

The reliance on managerial heuristics is recognized as a source of systematic decision errors (Anderson, 2000; Garvin \& Roberto, 2001) and has been linked to poor FFE outcomes (Cooper, 1997). However, managerial heuristics also provide a quick and inexpensive way to clear the product evaluation system of unwanted ideas before they eat up resources for front-end evaluation (Crawford \& di Benedetto, 2007; van Riel et al., 2011). Furthermore early decision errors are assumed to have no severe consequences: if a good idea is wrongly rejected through managerial judgement, there are always other good ideas that can come in its place (Reinertsen, 1999) . Also, if a bad idea is wrongly accepted, it does not cost much to mature it a little further and correct the mistake at a later decision gate that is based on more analytical approaches (Reinertsen, 1999). Heuristics are consequently accepted as an inferior, but nevertheless useful decision approach, as long as it limited to routine decision or very early screening decisions that can be revised later, and as long as decision-makers strive to reduce their biases by making team, rather than individual decisions, by keeping records, and by providing sufficient background data (Crawford \& di Benedetto, 2007). However, for important and complex problems, with multiple and possibly conflicting objectives and high levels of 
uncertainty rational decision models are generally recommended (Klein, 2009). Accordingly, the use of non analytical factors and personal judgment in project selection has been widely criticized (Murphy \& Kumar, 1997; Cooper, 1999).

Recent research in psychology challenges this view: based on Simon's concept of "satisficing" (Simon \& Newell, 1958) it has re-discovered heuristic decision making, and particularly so-called "Fast and Frugal” (F\&F) heuristics, as a means to reach "good enough" decisions in complex situations that are characterized by multiple decision criteria, high uncertainty and time pressure (Gigerenzer \& Goldstein, 1996). F\&F heuristics are heuristics that consist of three elements: a search rule that looks up factors in order of importance, a stopping rule that stops the search if a factor is found that allows to discern alternatives, and a decision rule that classifies the object under review according to this factor (Gigerenzer, 2007). F\&F heuristics provide one (but not the only) explanation for intuitive judgments. Intuitive judgements occur quickly, are made consciously, and are strong enough to act upon, but occur without full awareness of the underlying reasons (Gigerenzer, 2007). Rather than perceiving heuristics as a poor decision approach that should be limited to simple problems and to situations in which poor decisions can be revised later on, research on F\&F heuristics sees them as a potentially superior decision strategy (Klein, 2003; Gigerenzer, 2007). This view has influenced the popular business literature and has led to bestselling books on the value of managerial intuition (Gladwell, 2005; Gigerenzer, 2007). However, to date, little is known about the product screening heuristics managers use, let alone the quality of heuristics-based project selection decisions. This paper contributes to the understanding of the efficacy of decision heuristics in project screening through a decision experiment that is based on an illustrative data set we develop product screening specific models of three well known generic fast and frugal (F\&F) heuristics, namely, Take-the-Best (TTB), Tallying, and Elimination-byAspect (EBA) and discuss their respective ability to correctly select good product ideas and reject bad ones. We furthermore compare their performance against the performance of variations of a regression model because regression models are frequently used as a model for compensatory judgment behaviour (Dhami \& Harries, 2001) and prescribed as the optimal way to integrate information for the purpose of estimation and forecasts (Gigerenzer \& Goldstein, 1996).

This research explores the performance of F\&F heuristics in FFE screening and faces three challenges: First, F\&F decision making has been predominantly investigated for less complex decision problems that have lower stakes than project screening, such size estimates for cities (Gigerenzer, 2007). As a consequence, models of project-screening specific F\&F heuristics have to be generated for the first time. Second, current research on F\&F heuristics is still investigating, which fast and frugal strategies decision-makers truly employ in a non-laboratory setting. It is therefore unknown if the F\&F models identified in this paper appropriately describe judgment behaviour in the fuzzy front-end, particularly since heuristics are known to differ between individual decision makers (Bröder, 2000; Newell, Weston, \& Shanks, 2003). The research therefore focuses on the commonly recognized, generic F\&F heuristics that are at the core of individualized heuristics. Future field studies will have to investigate, how decision-makers' personal heuristics differ from the generic F\&F heuristics. Third, this research uses an illustrative data set of front-end projects and screening criteria because real world data on very early screening decisions, particularly about rejected 
projects does not exist in the field. The research therefore cannot identify the F\&F heuristic that generally best predicts project success. Instead, it explores the decision outcomes of alternative decision approaches by using the identical data set for all alternatives.

Our investigation starts with a brief review of the literature on heuristic and F\&F decision making in Section 2. Section 3 describes the elements of our research approach: the generation of an illustrative data set of 52 projects that is used for project screening (3.1); a regression analysis based on the illustrative dataset that is used for project screening by forecasting future product success (3.2), and the modelling of three F\&F heuristics for project selection, that are project-screening specific adaptations of more general F\&F models described in the literature (3.3). Section 4 applies the three F\&F models and the regression model and two of its variants to the data set of 52 projects and discusses the different models' ability to correctly discern successful and unsuccessful projects. The results and their implications are discussed in Section 5.

\section{Background}

\subsection{Simple Heuristics}

Heuristics are simple strategies or rules of thumb for solving certain kinds of problems (March, 1994). They follw a logic different than consequence logic to minimize the amount of mental effort invested in making a decision (March, 1994; Rieskamp \& Hoffrage, 1999; Fasolo, McClelland, \& Todd, 2007; Gigerenzer, 2007; Glöckner \& Betsch, 2008), and cannot guarantee optimal solutions (Perkins \& Salmon, 1989). Heuristics are part of a decision maker's acquired repertoire of cognitive strategies for solving judgment problems (Reimer \& Rieskamp, 2007). They trade off the effort involved in making a choice against the accuracy of that choice (Payne, Bettman, \& Johnson, 1993; Eisenhardt \& Sull, 2001): instead of taking all available information into consideration, they focus on only one or very few cues that suffice to discern decision alternatives in a particular situation. They are, therefore, characterized as ecologically rational (Goldstein \& Gigerenzer, 2002) to contrast them against the concept of rationality as optimization.

Research on fast and frugal heuristics frequently attempts to uncover and model the structure of human heuristics to understand the nature of the internal, only partially conscious decision processes people employ in real-world decision situations. Studies often include a pre-defined set of heuristics, and assess which of these heuristics is the best predictor of subject's actual choices (Bröder, 2000; Dhami \& Harries, 2001; Scheibehenne, Miesler, \& Todd, 2007; Snook, Dhami, \& Kavanagh, 2010). For example, for food decisions, simple lexicographic heuristic that only consider each participant's most important factors appear to be as good at predicting participants' food choices as a weighted additive model that takes all factors into account (Scheibehenne et al., 2007). Similarly, a non-compensatory matching heuristic that searches for only one or very few 
cues describes doctors' decision to prescribe or not prescribe medication equally well as a regression model (Dhami \& Ayton, 2001). Furthermore, English magistrates' decisions on bailing are better described and predicted by a fast and frugal model characterized by non-compensatory cue use, than by either of two compensatory integration models (Dhami \& Harries, 2001). However, studies also find considerable individual (Bröder, 2000; Newell et al., 2003) and age (Besedes, Deck, Sarangi, \& Shor, 2009) differences in the extent to which people use these heuristics.

A second and related stream of heuristics research demonstrates and advocates for the adequacy of heuristics as a shortcut decision rule that can approximate "rational" decision-making: Andersson's research (Andersson, Ekman, \& Edman, 2003) shows that naïve respondents who employ a simple recognition heuristic and predict the outcome of the 2002 Soccer World Cup based on the assumptions that teams that they have heard about will win, outperform experts who review and weigh detailed information about the teams. Astebro and Elhedhli (Astebro \& Elhedhli, 2006) investigate the decision behaviour of a panel of experts that predicts the success of entrepreneurial start-ups and model the experts' decision approach as a simple conjunctive heuristic that ignores some cues and weighs all other cues the same. This simple heuristic outperforms a statistically derived decision rule with optimal weights. Similarly, Perry (2008) investigates the performance of an early warning system for conflicts in Sub-Saharan Africa that draws on only three, instead of the commonly used dozens of indicators and nevertheless correctly predicts all occurring conflicts (though it wrongly predicts some conflicts that did not occur). Gigerenzer and others embark on a research program to investigate the structure and efficacy of various heuristics that they characterize as "fast and frugal", such as a recognition heuristics (Goldstein \& Gigerenzer, 2002), “Take The Best”, “Tallying” (Goldstein \& Gigerenzer, 2002; Gigerenzer, Czerlinski, \& Martignon, 2003), and Elimination by Aspect (Payne, James R. Bettman, \& Johnson, 1988; Berretty, Todd, \& Blythe, 1997; Laurent, 2006). Their research demonstrates that F\&F heuristic frequently outperform other, more complex inference procedures, such as multiple regression in speed and sometimes in accuracy because "a complex strategy can fail because it explains too much in hindsight. Only part of information is valuable for future, and the art of intuition is to focus on that part and ignore the rest. A simple rule that relies only on the best clue has a good chance of hitting on that useful piece of information." (Gigerenzer, 2007 p. 58).

\subsection{Heuristics for the Fuzzy Front End of New Product Development}

The fuzzy front-end stages of product development encompass planning activities, including opportunity recognition, product concept generation and screening, and business case development that take place before a product development project is launched (Nobelius \& Trygg, 2002). They are characterized by high levels of uncertainty: information is typically incomplete, not accessible, and sometimes inconsistent. Furthermore, decisions usually have to be made under time constraints with little prior research (Cooper \& Kleinschmidt, 1986; 1993; Cooper, 1999). Consequently, managers heavily rely on their personal judgment in order to decide which project ideas to fund and to subsequently move to development and which ones to abandon (Cooper \& Kleinschmidt, 1986; Murphy \& Kumar, 1997; Burke \& Miller, 1999; Anderson, 2000; Khatri \& Alvin, 2000; Koen et al., 
2002). Their decision approaches are based on single or very few decision criteria and are consequently largely at odds with the detailed catalogues of decision criteria for new project selection that are proposed in the literature (Cooper, 1985; Calantone et al., 1999; Lin \& Chen, 2004; Chin, Xu, Yang, \& Lam, 2008). These catalogues contain up to 45 (Cooper, 1985) different criteria for project selection in the areas of strategic alignment, market attractiveness, resource constraints, and technical feasibility (Jetter, 2005) and even short catalogues still list 13 criteria (Calantone et al., 1999). In this paper, we are investigating how decisions based on a single or very few criteria perform in comparison to decisions that follow the recommendation to take many criteria into account. Since it is currently unknown which heuristics managers use to select or reject new product development projects, we adapt three well-documented and frequently used F\&F decision heuristics to a project selection problem, namely, Take-theBest, Tallying, and Elimination-by-Aspect.

\section{Research Design}

\subsection{Evaluation criteria and data set}

This research aims to assess and compare the performance and biases of F\&F project screening heuristics and regression models by applying each screening approach to the same data set of unscreened, early-stage product ideas. In real-world settings, such a data set does not exist because project ideas reach decision-makers in an ad-hoc, unplanned fashion, are undocumented and are only communicated across the organization if the first screen is favourable (Stevens \& Burley, 1997) Earlier research on screening behaviour and decision support therefore uses a small set of simulated new product project descriptions (Calantone et al., 1999) or real-world cases of mature entrepreneurial start-up, rather than product ideas (Astebro \& Elhedhli, 2006). To overcome the lack of data, we generate an illustrative data set of project ideas that is based on empirical research on screening criteria and criteria for product development success.

As discussed above, prior researches on decision criteria for screening new products (Cooper, 1985; Calantone et al., 1999; Lin \& Chen, 2004; Chin et al., 2008) identify a wide range of different criteria. However, some criteria are consistently mentioned and commonly agreed upon, namely financial criteria (profitability of the project, risks, payback period), superiority of the planned product, market criteria (market attractiveness, competitive situation), and feasibility considerations. Accordingly, van Riel et al. conclude that new product ideas are usually evaluated for feasibility, risk and market potential under high levels of uncertainty (van Riel et al., 2011). Based on these findings, we have identified seven criteria that are commonly used to forecast project outcome in product screening. For example, project with high risk, long payback periods, or poor product superiority are expected to fail and are rejected, whereas projects that do well in all or almost all criteria are expected to succeed and will be funded. The seven evaluation criteria do not carry the same weight: for example, when screening the R\&D ideas of technology entrepreneurs, (Astebro, 2004) found that expected profitability, development risk, function help explain the decision to 
commercialize a product idea or reject it much more so than other criteria. At the FFE, quantitative data for each criterion is typically not available as criteria are evaluated based on a relatively vague product concept (Hammedi et al., 2011); therefore, projects in our illustrative dataset will be evaluated using linguistic variables (Lin \& Chen, 2004) with four evaluation levels: "Very Good" when a project has a high probability to perform well with regard to the criterion; "Good" when a project is evaluated to satisfy the criterion; "Neutral" when the project is expected to neither support nor be detrimental to the criterion and "Poor" if the evaluation of the project does not satisfy this criterion. Table 1 provides the criteria that will be used, along with explanations of the linguistic variables. Note that we do not differentiate between "poor" and "very poor" performance because we expect decision makers to require less granularity for bad outcomes than for good outcomes; e.g. they are unlikely to differentiate between a financial loss and a large financial loss.

TABLE 1: SCREENING CRITERIA USED TO EVALUATE PROJECTS

\begin{tabular}{|c|c|c|c|}
\hline Criteria & Explanation & Evaluation & Verbal Value \\
\hline Profitability & $\begin{array}{l}\text { Is the project expected to be } \\
\text { profitable? }\end{array}$ & $\begin{array}{ll} & \text { High profit expected } \\
\text { - } & \text { Good profit expected } \\
\text { - } & \text { Profit hard to predict } \\
\text { - } & \text { Financial loss expected }\end{array}$ & $\begin{array}{ll}- & \text { Very good } \\
\text { - } & \text { Good } \\
\text { - } & \text { Neutral } \\
\text { - } & \text { Poor }\end{array}$ \\
\hline Risk & $\begin{array}{l}\text { How much uncertainty exists in } \\
\text { bringing the project to the } \\
\text { market? }\end{array}$ & $\begin{array}{ll}\text { - } & \text { Low risk } \\
\text { - } & \text { Medium risk } \\
\text { - } & \text { Unknown } \\
\text { - } & \text { High risk }\end{array}$ & $\begin{array}{ll}\text { - } & \text { Very good } \\
\text { - } & \text { Good } \\
\text { - } & \text { Neutral } \\
\text { - } & \text { Poor }\end{array}$ \\
\hline Product Superiority & $\begin{array}{l}\text { Does the product provide a } \\
\text { unique advantage to the } \\
\text { customer? }\end{array}$ & $\begin{array}{ll}\text { - } & \text { New product function / } \\
\text { value dimension } \\
\text { - } & \text { Better performance on } \\
\text { existing value dimension } \\
\text { - } \quad \text { New design, same } \\
\text { performance } \\
\text { - } \quad \text { No differentiation } \\
\end{array}$ & $\begin{array}{ll}- & \text { Very good } \\
\text { - } & \text { Good } \\
\text { - } & \text { Neutral } \\
\text { - } & \text { Poor }\end{array}$ \\
\hline Project Feasibility & $\begin{array}{l}\text { Does the project fit available } \\
\text { resources? }\end{array}$ & 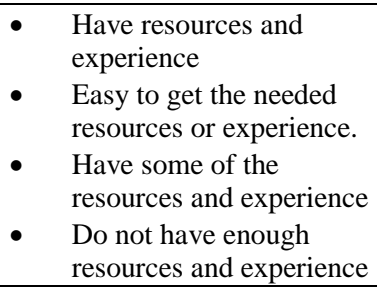 & $\begin{array}{ll}\text { - } & \text { Very good } \\
\text { - } & \text { Good } \\
\text { - } & \text { Neutral } \\
\text { - } & \text { Poor }\end{array}$ \\
\hline Market Attractiveness & $\begin{array}{l}\text { Is the market sufficiently large } \\
\text { and will it grow further? }\end{array}$ & $\begin{array}{ll}- & \text { Large/growing } \\
\text { - } & \text { Medium/stable } \\
\text { - } & \text { Small/unpredictable } \\
\text { - } & \text { Shrinking }\end{array}$ & $\begin{array}{ll}\text { - } & \text { Very good } \\
\text { - } & \text { Good } \\
\text { - } & \text { Neutral } \\
\text { - } & \text { Poor }\end{array}$ \\
\hline Payback Period & $\begin{array}{l}\text { How long will it take to get the } \\
\text { investment back? }\end{array}$ & $\begin{array}{ll}\text { - } & \text { Very Short period } \\
\text { - } & \text { Reasonably short period } \\
\text { - } & \text { Still acceptable or } \\
& \text { unknown } \\
\text { - } & \text { Long }\end{array}$ & $\begin{array}{ll}\text { - } & \text { Very good } \\
\text { - } & \text { Good } \\
\text { - } & \text { Neutral } \\
\text { - } & \text { Poor }\end{array}$ \\
\hline
\end{tabular}




\begin{tabular}{|c|c|c|c|}
\hline Competitive Situation & $\begin{array}{l}\text { How strong are current and } \\
\text { future competitors? }\end{array}$ & 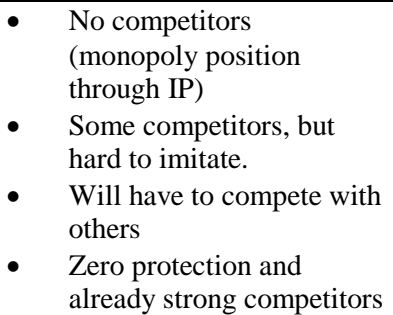 & $\begin{array}{ll}- & \text { Very good } \\
\text { - } & \text { Good } \\
\text { - } & \text { Neutral } \\
\text { - } & \text { Poor }\end{array}$ \\
\hline
\end{tabular}

To generate the illustrative data set, we create 52 projects and describe them with regard to the seven main criteria and the expected final project performance (Success or 1, Failure or 0). To model incomplete information, some criteria values are left blank. Table 2 shows example from the dataset; the complete set is included in the appendix. The dataset contains $60 \%$ failed (31 projects) and $40 \%$ successful (21 projects) because this is the mix of successful and unsuccessful projects that are screened in the front-end as reported by (Barczak, Griffin, \& Kahn, 2009). Project outcomes were assigned according to plausibility considerations, given the characteristics of the project: for example, project \#52 in table 2 has most characteristics of a potentially successful project and was therefore labelled a success. With the project information available, projects 30 and 32 seem equally likely to result in a success than in a failure. In these cases, a project outcome was chosen randomly. This approach to data generation naturally has limitations and may result in a dataset that is different from what project screeners encounter in the real-world. Due to lack of real-world data, we do not know if and how our data set is biased. However, in this research we do not intend to identify the method that generally best predicts project success, but explore the decision outcomes of alternative decision approaches by using the identical data set for all alternatives. Any bias thus equally applies to all screening methods.

TABLE 2:EXAMPLE OF DATA SET: Projects 30-32 and 52

\begin{tabular}{|l|l|l|l|l|l|l|l|l|}
\hline & Profitability & Risk & Superiority & $\begin{array}{l}\text { Technical } \\
\text { Feasibility }\end{array}$ & Market & Payback & $\begin{array}{l}\text { Competi- } \\
\text { tion }\end{array}$ & Outcome \\
\hline P\#30 & & Good & Neutral & Neutral & Neutral & Poor & Failure \\
\hline P\#31 & Poor & Neutral & Neutral & Neutral & Neutral & Neutral & \\
\hline P\#32 & Very Good & Poor & Very Good & Poor & Very Good & Poor & Very Good & Success \\
\hline P\#52 & Good & Good & Neutral & Good & Very Good & Poor & Neutral & Success \\
\hline
\end{tabular}

\subsection{Regression Modelling}

Regression models are statistical models, widely used for predicting and forecasting, and for understanding which among the independent variables are related to the dependent variable (Sykes, 1993; Field, 2005; Freedman, 2005). They are frequently used as a descriptive model of human judgment (Dhami \& Harries, 2001) and are prescribed as an optimal approach to integrating information (Gigerenzer \& Goldstein, 1996). Studies have furthermore compared the fit of F\&F models with that of regression models on human judgment data (Rieskamp \& Hoffrage, 1999; Slegers, Brake, \& Doherty, 2000; Dhami \& Harries, 2001) and simulated judgment data (Gigerenzer \& Goldstein, 1996; Rieskamp \& Hoffrage, 1999). Multiple logistic regressions is a technique that allows additional factors to enter the analysis separately so the effect of each factor can be estimated, when the 
outcome variable has a categorical (usually binary) value (Taylor, 2009). In this study, since we have several explanatory (predictor) variables (the criteria), with a binary response (project success or failure), we use the multiple logistic regression technique which is given as:

$$
\pi\left(x_{1}, \ldots x_{p}\right)=P(Y=1: \mathrm{X} 1=\mathrm{x} 1 ; \ldots ; \mathrm{Xp}=\mathrm{xp})
$$

Where, $y$ is Bernoulli with a probability that depends on covariates $\mathrm{f}$ (X1....;Xp) (Field, 2005; Taylor, 2009). The logistic regression model uses the following equation:

$$
\mathrm{P}(\mathrm{y})=\frac{1}{1+\mathrm{e}^{-\mathrm{z}}}
$$

In which:

$\mathrm{P}(\mathrm{y})$ is the probability of $\mathrm{Y}$ occurring

$e$ is the base of natural logarithms

$\mathrm{z}=\mathrm{b}_{0}+\mathrm{b}_{1} \mathrm{x}_{1}+\mathrm{b}_{2 \times 2}+\ldots+\mathrm{b}_{\mathrm{p}} \mathrm{x}_{\mathrm{p}}$

$\mathrm{b}_{0}=\mathrm{a}$ constant.

$\mathrm{x}_{\mathrm{i}}=\mathrm{a}$ criterion (predictor)

$b_{i}=$ coefficient or weight attached to a predictor.

The result of the equation is a probability value represented by a number between 0 and 1 . If the probability is closer to 0 , it means (y) (project success in our case) is very unlikely to occur, and if it is closer to 1, it means (y) (project success in our case) is more likely to occur.

The object of multiple logistic regressions is to discover what combinations of explanatory variables provide the best fit for the observed proportions. Since some means for determining the significance of the estimates of the model parameters, and a means for assessing the fit, or lack of fit, of the logistic model are needed, correlations that may exist between explanatory variables will be studied (Cook, Dixon, Duckworth, Kaiser, Koehle, Meeke, \& Stephenson, 2001). The coefficients' values are estimated by fitting the model depending on the variable predictor to observed data (Field, 2005). logistic regression 'inference is often based on the deviance which is twice the log-likelihood ratio (Cook et al., 2001). The large value of the deviance (loglikelihood statistic) indicates a poor fit of the statistical model (Field, 2005).

This logistic regression model uses the seven most important criteria as the independent variables, and the response (predicting project success or failure) as the dependent variable. Criteria were entered simultaneously into the regression 
equation. The logistic regression analysis indicates the predicted probability of a project's success. The logistic regression model equation for predicting project performance based on the illustrative data set has the following values:

$$
\begin{gathered}
P(y)=\frac{1}{1+\mathrm{e}^{-\mathrm{z}}} \quad \text { where } \\
\mathrm{z}=-9.24+2.5(\text { profit })+.599(\text { risk })+.616(\text { sup })+.805(\text { tech })-1.57(\text { mkt })-.663(\text { paybk })+.14 \text { (protect) }
\end{gathered}
$$

This model classified 27 failed projects correctly, and misclassified four failed projects. In addition, it classified 15 successful projects correctly and misclassified 6 projects. It thus can predict project failure correctly $87.09 \%$ of the time, project success correctly $71.4 \%$ of the time, and overall, correctly classifies $80.7 \%$ of the projects, as summarized in Table 3 . Table 4 reports the chi-square statistics as 57.09 , which is significant at $\mathrm{p}<.0001$, followed by the model summary.

\begin{tabular}{|c|c|c|c|c|}
\hline & \multicolumn{3}{|c|}{ Predicted Project Performance } \\
\hline & & Failure & Success & $\begin{array}{l}\text { Percentage } \\
\text { Correct }\end{array}$ \\
\hline \multirow{2}{*}{$\begin{array}{l}\text { Observed Project } \\
\text { Performance }\end{array}$} & Failure & 27 & 4 & 87.09 \\
\hline & Success & 6 & 15 & 71.4 \\
\hline \multicolumn{4}{|l|}{ Overall Percentage } & 80.7 \\
\hline
\end{tabular}

TABLE 3:CLASSIFICATION TABLE OF LOGISTIC REGRESSION MODEL USING 7 CRITERIA

\begin{tabular}{|c|c|c|c|c|c|}
\hline \multicolumn{6}{|c|}{ Omnibus Tests of Model Coefficients } \\
\hline & & \multicolumn{2}{|c|}{ Chi-square } & Df & Sig. \\
\hline \multirow[t]{3}{*}{ Step 1} & Step & \multicolumn{2}{|l|}{57.094} & 7 & .000 \\
\hline & Block & \multicolumn{2}{|l|}{57.094} & 7 & .000 \\
\hline & Model & \multicolumn{2}{|l|}{57.094} & 7 & .000 \\
\hline \multicolumn{6}{|c|}{ Model Summary } \\
\hline Step & \multicolumn{2}{|c|}{-2 Log likelihood } & \multicolumn{2}{|c|}{\begin{tabular}{|lll} 
Cox \& & Snell & $\mathrm{R}$ \\
Square & &
\end{tabular}} & Nagelkerke R Square \\
\hline 1 & \multicolumn{2}{|l|}{$85.685^{\mathrm{a}}$} & \multicolumn{2}{|c|}{.426} & .567 \\
\hline
\end{tabular}

TABLE 4:CHI-SQUARE AND MODEL SUMMARY FOR LOGISTIC REGRESSION MODEL USING ALL VARIABLES

\subsection{Modelling simple heuristics}

\section{First proposed model: Take-the-Best}

A useful Take-the-Best (TTB) model for project screening has to evaluate projects individually, rather than through comparison with other projects, because very early stage project ideas typically reach decision-makers one-by-one. Furthermore, a selection model that evaluates project performance relative to other projects runs the risk of choosing the best of bad projects, 
rather than rejecting all of them. Building on the concepts used in earlier research (Gigerenzer \& Goldstein, 1996) we modelled a "Take-the-Best" model for new product screening that forecast the success of each project individually by focusing on the first criterion that discerns between positive and negative project forecasts (see figure 1). It starts by evaluating the most important criterion-in our case project profitability. If it is evaluated as "Very Good" or "Good", the search for information stops, the project idea is accepted, and the project moves to the next stage of the fuzzy front-end. If the criterion has been evaluated as "Poor", the search for further information stops as well, but the project idea is rejected. If the criterion has a "neutral" value (neither high nor low profit expectations) or the project profitability is unknown, the model looks at the next criterion - in our case risk - and repeats the prior steps. If, after studying all criteria, most criteria are neutral or unknown, the model cannot make a decision and will recommend to further study the project idea, which results in a temporary rejection of the project. Table 5 shows sample projects and their evaluation, using the TTB model.

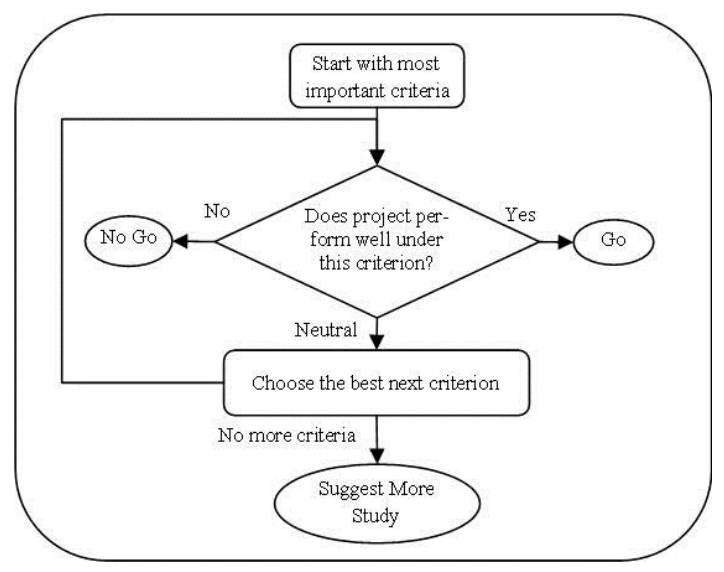

FIGURE 1: TAKE THE BEST MODEL

TABLE 5: EXAMPLES OF PROJECTS \#32-34, EVALUATED USING TAKE THE BEST MODEL

\begin{tabular}{|l|l|l|l|l|l|l|l|l|}
\hline & Profitability & Risk & Superiority & Feasibility & Market & Payback & Competition \\
\hline P\#32 & & Good & Neutral & Neutral & Neutral & Poor & & \\
\hline P\#33 & Poor & Neutral & Neutral & Neutral & Neutral & Neutral & \\
\hline P\#34 & Very Good & Poor & Very Good & Poor & Very Good & Poor & Very Good & Reject \\
\hline
\end{tabular}

\section{Second proposed model: Tallying model}

A Tallying model does not evaluate criteria in any particular order, but makes a decision based on a minimum number of criteria $\mathrm{p}$ that indicate a positive project outcome or a maximum number of criteria $\mathrm{n}$ that predict a negative project outcome. Once the minimum or maximum is reached, it stops searching for more information. To keep our proposed model simple, the model will cumulatively assess all seven criteria: $p=n=7$. Each “Very good" receives a score of (+2), “Good” a score of (+1), "Poor" a score of $(-1)$ and "Neutral" a score of zero (0). If the total value is positive, then the Tallying model will recommend taking the idea to next stage. If the total value is zero or negative then idea will be rejected. Using the proposed Tallying method, the criteria 
will be randomly evaluated and a counter will be used to add two points for each "Very Good" criterion, to add one point for each "Good" criterion, and to subtract one point for each criterion evaluated as "Poor". The counter value will not change for any unknown value or any neutral evaluation. Fig. 2 shows the flowchart for the model, and Table 6 shows the sample projects with evaluation values and decision outcomes.

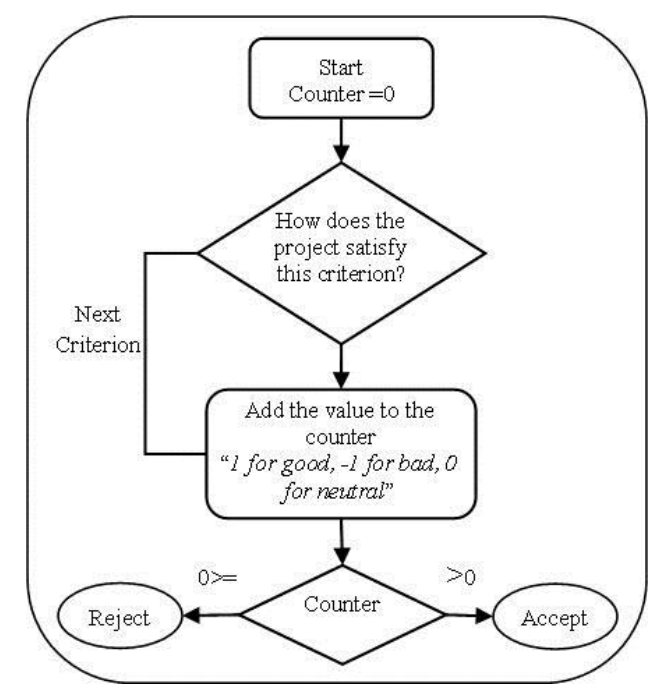

FIGURE 2.TALLYING MODEL

TABLE 6: EXAMPLE OF PROJECTS 32-34, EVALUATED USING TALLYING MODEL

\begin{tabular}{|l|l|l|l|l|l|l|l|l|l|}
\hline & $\begin{array}{l}\text { Profit- } \\
\text { ability }\end{array}$ & Risk & Superiority & Feasibility & Market & Pay-back & $\begin{array}{l}\text { Competit } \\
\text { ion }\end{array}$ & $\begin{array}{l}\text { Counter } \\
\text { for } \\
\text { Tallying }\end{array}$ & $\begin{array}{l}\text { Decision } \\
\text { Using } \\
\text { Tallying }\end{array}$ \\
\hline P\#32 & & Good & Neutral & Neutral & Neutral & Poor & & 0 & Reject \\
\hline P\#33 & Poor & Neutral & Neutral & Neutral & Neutral & Neutral & & -1 & Reject \\
\hline P\#34 & Very Good & Poor & Very Good & Poor & $\begin{array}{l}\text { Very } \\
\text { Good }\end{array}$ & Poor & $\begin{array}{l}\text { Very } \\
\text { Good }\end{array}$ & 5 \\
\hline
\end{tabular}

\section{Third proposed model: Elimination-by-aspect}

Elimination-by-Aspect (EBA) as a model of probabilistic choice was first proposed by Tversky (Tversky, 1972). He realized that decision makers who face many decision alternatives minimize memory load by focusing on one criterion or a small subset of criteria, for which they determine a cut-off value. The criteria are chosen based on their perceived importance and validity. All alternatives that do not meet the minimum threshold are excluded from further consideration. In a next decision step, the decision makers may subsequently focus on another (slightly less valid and important) criterion or subset of criteria and continue the process until they can reach a decision. Subsequent research (Payne et al., 1988; Berretty et al., 1997) showed that EBA is an efficient heuristics within the adaptive toolbox because it achieves balance between cognitive cost and decision quality. 
For the purpose of this research, we design an EBA decision model to screen new project ideas that is based on Tversky's concept: our model tests the four most important criteria (profitability, risk, superiority, and feasibility - in this order) at a time. The threshold for acceptance is that at least two evaluation values are either "good" or "excellence". The threshold for final rejection (project elimination) is that two evaluation values are either "poor" or "unknown" or that all three evaluation values are only "fair". If the evaluation values neither meet the acceptance, nor the elimination threshold the model postpones the decision and seeks more information, which results in a temporary rejection of the project. Fig. 3 shows the flowchart for the model, the criterion values for the three sample projects are described in Table 7.

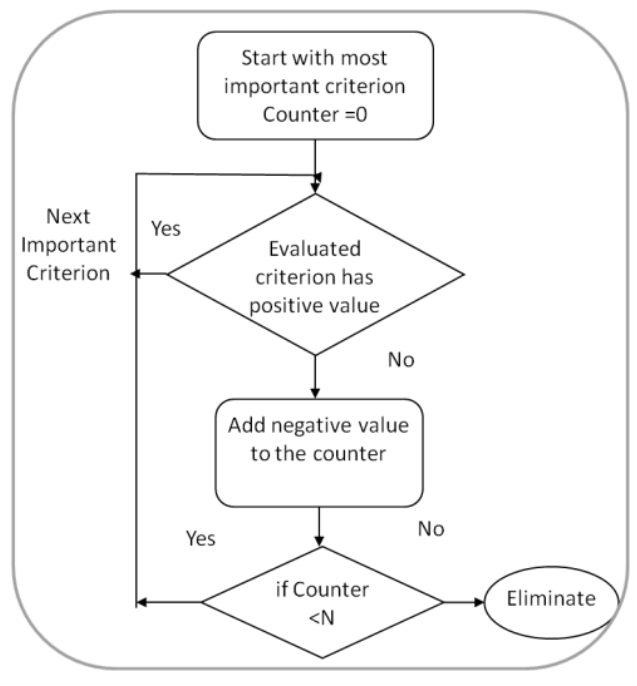

Figure 3. EBA MODEL

TABLE 7. EXAMPLE OF PROJECTS \#32-34, EVALUATED USING ELIMINATION-BY-ASPECT

\begin{tabular}{|l|l|l|l|l|l|l|l|l|}
\hline & Profitability & Risk & Superiority & Feasibility & Market & Payback & Competition & Decision Using EBA \\
\hline P\#32 & & Good & Natural & Natural & Natural & Poor & & $\begin{array}{l}\text { Seek } \\
\text { information }\end{array}$ \\
\hline P\#33 & Poor & Natural & Natural & Natural & Natural & Natural & & Reject \\
\hline P\#34 & Very Good & Poor & Very Good & Poor & $\begin{array}{l}\text { Very } \\
\text { Good }\end{array}$ & Poor & Very Good & Reject \\
\hline
\end{tabular}

\section{Data Analysis and Discussion}

\subsection{Results for Take-the-Best Model}

The TTB heuristic reaches a decision with little information: it searched through only 1 out of 7 criteria $(K=1)$ in $92 \%$ of the cases and through 2 criteria $(\mathrm{k}=2)$ in $5.77 \%$ of the cases in our data set. The maximum number of criteria that were 
considered was $3(\mathrm{k}>=3)$ in $2 \%$ of all cases. The heuristic predicted project performance correctly $55.77 \%$ of the time. It was much more powerful at predicting project success than failure: while it correctly predicted failure at a rate of just $32.25 \%$, it predicted project success correctly for $90.47 \%$ of all projects. A summary of the results is presented in Table 8 .

TABLE 8: STATISTICAL ANALYSIS FOR TTB MODEL PERFORMANCE

\begin{tabular}{|c|c|c|c|c|}
\hline & \multicolumn{3}{|c|}{ Predicted Project Performance } \\
\hline & & Failure & Success & $\begin{array}{l}\text { Percentage } \\
\text { Correct }\end{array}$ \\
\hline \multirow[t]{2}{*}{$\begin{array}{l}\text { Observed Project } \\
\text { Performance }\end{array}$} & Failure & 10 & 21 & 32.25 \\
\hline & Success & 2 & 19 & 90.47 \\
\hline \multicolumn{4}{|l|}{ Overall Percentage } & 55.77 \\
\hline
\end{tabular}

Despite mostly using only one criterion, the model identifies successful projects with high accuracy. Its overall performance, however, is only slightly better than flipping a coin. It is therefore not suitable for making final project screening decisions - too many unsuccessful projects would receive funding. However, the projects that are selected by the heuristic have a much greater probability of success than the general pool of projects they come from. Using the simple heuristic can thus help decision makers to quickly identify projects that should be studied further until a subsequent decision gate.

\subsection{Results for Tallying model}

The Tallying model goes through all 7 key criteria, adds the coded value for each criterion to the counter, and checks the final value of the counter. Other than sophisticated multi-criteria decision approaches, it gives all criteria the same weight. It predicts project performance correctly in about $77 \%$ of all cases. It is better at recognizing successful projects than unsuccessful ones and correctly predicted $81 \%$ of the successes and $74 \%$ of the failures. These results are summarized in Table 9 .

TABLE 9: STATISTICAL ANALYSIS FOR TALLYING MODEL PERFORMANCE

\begin{tabular}{|c|c|c|c|c|}
\hline & \multicolumn{3}{|c|}{ Predicted Project Performance } \\
\hline & & Failure & Success & $\begin{array}{l}\text { Percentage } \\
\text { Correct }\end{array}$ \\
\hline \multirow{2}{*}{$\begin{array}{|ll|}\text { Observed } & \text { Project } \\
\text { Performance } & \\
\end{array}$} & Failure & 8 & 23 & 74.19 \\
\hline & Success & 4 & 17 & 80.95 \\
\hline \multicolumn{4}{|l|}{ Overall Percentage } & 76.92 \\
\hline
\end{tabular}

\subsection{Results for Elimination by Aspect Model}


The EBA model goes through the top four key criteria, adds the coded value for each criterion to a counter and then checks the final value of the counters to determine if the threshold for elimination or rejection is met. If no threshold value is met, the model temporarily rejects the project and asks for further study of additional criteria. It predicts project performance correctly in about $69 \%$ of all cases. It is better at recognizing bad projects than successful ones and correctly predicts $77.4 \%$ of the failures and $57.14 \%$ of the successes. These results are summarized in Table 10.

TABLE 10: STATISTICAL ANALYSIS FOR EBA MODEL PERFORMANCE

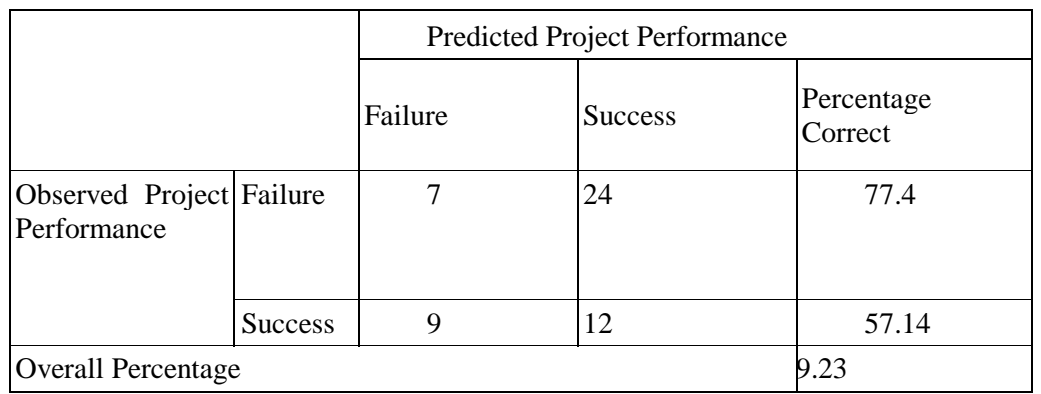

\subsection{Comparison and Discussion of Simple Heuristics}

The logistic regression and the proposed tallying model weight and integrate all available information on the seven project criteria, though in different ways. TTB uses a minimum number of evaluation criteria (less than three criteria) and EBA tests more than half of criteria: four out of seven. A comparison of the performance of all three models and the logistic regression model is presented in Fig.4. The results show that the logistic regression model outperforms the F\&F models in overall prediction quality and in the ability to predict project failure. However, with almost $77 \%$ correct predictions the Tallying model has an overall performance that is close to the logistic regression (80.7\%). Furthermore, both Tallying and TTB are better at correctly identifying good projects than the regression model. 


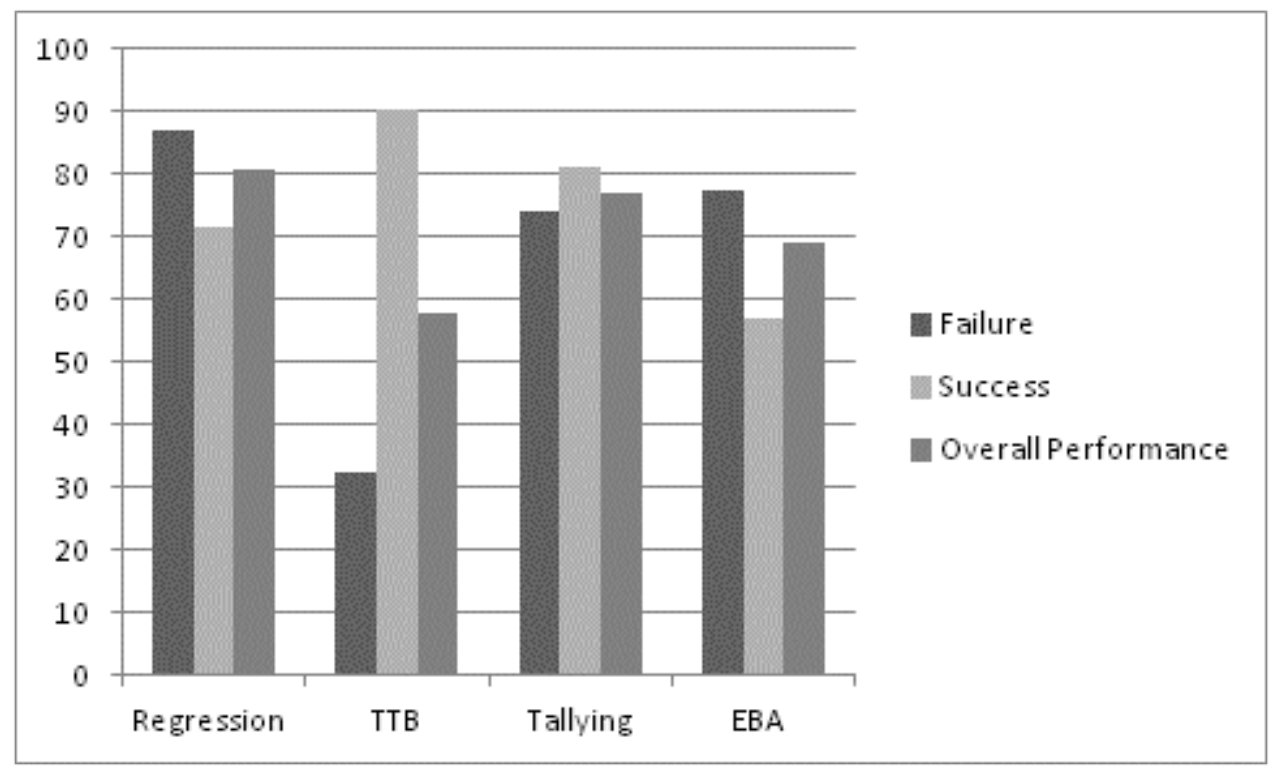

FIGURE.4. PERCENTAGE OF CORRECT PROJECT PERFORMANCE PREDICTIONS, USING REGRESSION, TTB, TALLYING, AND EBA MODELS

\subsection{Comparison and discussion of alternative regression models}

Researchers of F\&F decision making argue that in some instances, "less is more" and decision may improve when fewer criteria are considered (Rieskamp \& Hoffrage, 1999; Fasolo et al., 2007; Albar \& Kocaoglu, 2009). To test this idea, we run the regression model using one criterion (to compare the performance with TTB) and with four criteria (to compare the performance with EBA).

\section{Logistic regression model using a single variable}

Analyzing the project performance related to a single criterion (profitability), we obtain the following logistic regression equation:

$$
P(y)=\frac{1}{1+e^{-z}} \quad \text { where } z=-4.498+1.825(\text { prof })
$$

It correctly predicts a project's performance $75 \%$ of the time as shown in Table 11.

TABLE 11: PERFORMANCE ANALYSIS OF LOGISTIC REGRESSION MODEL USING SINGLE VARIABLE (PROFITABILITY)

\begin{tabular}{|c|c|c|c|c|c|}
\hline & \multirow[b]{3}{*}{ Observed } & & \multicolumn{3}{|c|}{ Predicted } \\
\hline & & & \multicolumn{2}{|c|}{ Project performance } & \multirow[b]{2}{*}{ Percentage Correct } \\
\hline & & & Failure & Success & \\
\hline \multirow[t]{3}{*}{ Step 1} & \multirow[t]{2}{*}{ Project performance } & Failure & 23 & 8 & 74.19 \\
\hline & & Success & 5 & 16 & 76.1 \\
\hline & \multicolumn{2}{|l|}{ Overall percentage } & & & 75 \\
\hline
\end{tabular}


TABLE 14: PERFOMANCE ANALYSIS OF LOGISTIC REGRESSION MODEL USING 4 VARIABLES

\begin{tabular}{|c|c|c|c|c|c|}
\hline & \multirow{3}{*}{\multicolumn{2}{|c|}{ Observed }} & \multicolumn{3}{|c|}{ Predicted } \\
\hline & & & \multicolumn{2}{|c|}{ Project performance } & \multirow[b]{2}{*}{ Percentage Correct } \\
\hline & & & Failure & Success & \\
\hline \multirow[t]{3}{*}{ Step 1} & \multirow[t]{2}{*}{ Project performance } & Failure & 27 & 4 & 87.09 \\
\hline & & Success & 5 & 16 & 76.19 \\
\hline & \multicolumn{2}{|c|}{ Overall percentage } & & & 82.69 \\
\hline
\end{tabular}

TABLE 15: CHI-SQUARE AND MODEL SUMMARY FOR LOGISTIC REGRESSION MODEL USING FOUR VARIABLES

\begin{tabular}{|c|c|c|c|c|c|}
\hline \multicolumn{6}{|c|}{ Omnibus Tests of Model Coefficients } \\
\hline & & & hi-square & Df & Sig. \\
\hline \multirow[t]{3}{*}{ Step 1} & Step & 53.497 & & 4 & .000 \\
\hline & Block & 53.497 & & 4 & .000 \\
\hline & Model & 53.497 & & 4 & .000 \\
\hline \multicolumn{6}{|c|}{ Model Summary } \\
\hline Step & \multicolumn{2}{|l|}{-2 Log likelihood } & Cox \& Snell R Square & & Nagelkerke R Square \\
\hline 1 & $89.282^{\mathrm{a}}$ & & .405 & & .540 \\
\hline
\end{tabular}

\section{Comparison of Results}

The performance of the three proposed F\&F models and the three logistic regression models (with 7 variables, 4 variables, and 1 variable) are displayed in Fig.5. This figure shows that the logistic regression model using four criteria has an overall prediction quality that outperforms the same model with more variables, as well as the regression model with only one variable. It also outperforms all F\&F models on the total average performance.

The regression models are conservative in their estimates of project success and reject between 28 and 33 projects out of the 52 projects. The F\&F models are more permissive in comparison and only reject between 12 and 18 projects. The regression models' high rejection rate leads to the rejection of many good projects and two of the three F\&F models (TTB and Tallying) outperform the regression models in this regard. The best F\&F model is Tallying, which identifies $81 \%$ of the successful and $74 \%$ of the unsuccessful projects correctly. Its performance is close to that of the best regression model, which correctly identifies $76 \%$ of the successes and $87 \%$ of the failures. The best model for predicting project success is the TTB model, which identifies $90 \%$ of successful cases, though at the expense of rejecting unsuccessful ones. 


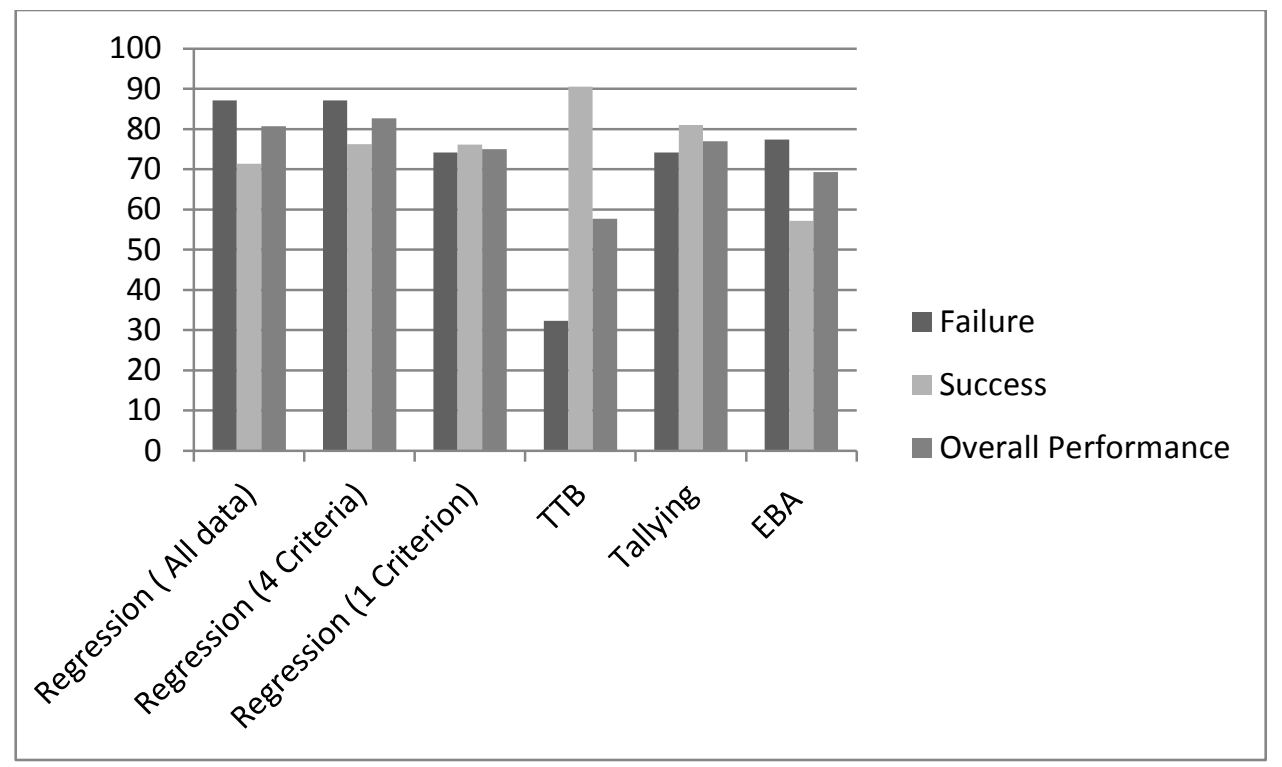

FIGURE 5: PERCENTAGE OF CORRECT PROJECT PERFORMANCE PREDICTIONS, USING 3 REGRESSION MODELS, TTB, TALLYING, AND EBA

\section{Implications, Limitations and Future Research}

This study explores the efficacy of F\&F models in very early new product screening, when information is scares and decision makers decide quickly and in an ad-hoc manner if they want to invest any resources into pursuing a project idea further. To this end, we adapted well-document F\&F strategies, namely TTB, Tallying, and EBA to the context of project screening and modelled each strategy to test its performances on a data set of 52 simulated projects. The results show that, for our illustrative dataset, two of the three F\&F strategies (TTB and Tallying) perform well at identifying winning projects and achieve accuracies over 80\%. Two of the three F\&F strategies (Tallying and EBA) furthermore do a good job at rejecting bad project ideas, achieving accuracies of over $70 \%$. F\&F strategies thin out the early front end funnel by reducing the number of projects by almost a third: EBA rejects 16 of 52 projects (30\%). Based on these findings, managerial judgment seems to provide a quick and no-cost decision gate that is "good enough" by the requirements laid out in the literature (Reinertsen, 1999; Crawford \& di Benedetto, 2007) - it does not seem to systematically discourage good ideas from finding a sponsor, it performs reasonably well at identifying bad projects and it efficiently reduced the resource needs for later stage evaluation. Our findings thus support the dominant view on managerial heuristics in front-end screening: they are not perfect, but in combination with additional, more sophisticated decision approaches, F\&F heuristics have a place in an efficient front-end evaluation system (Crawford \& di Benedetto, 2007).

F\&F heuristics sacrifice precision for simplicity and speed. To quantify this loss of performance, we compared heuristics against one sophisticated forecasting approach that is proposed for project screening (Cooper, 1985), as well as a model for 
human decision making (Dhami \& Harries, 2001): regression modelling. Since regression models build on objective data and consider all criteria in a compensatory fashion, they can be perceived as a theoretically ideal analytical decision method. In our study, the best regression model with four variables classified $82 \%$ of all projects correctly and thus outperformed the F\&F models. However, it performed poorer in picking winners than two of the F\&F heuristics and its performance was only slightly better than that of the best F\&F approach, which classified $77 \%$ of all projects correctly. This result could not be improved by feeding the model with more information. On the contrary, the regression model with seven variables performed worse: more information diluted the impact of those decision criteria that had the strongest impact on project success. This less-is-more effect is frequently reported in the literature on decision making (Gladwell, 2005; Albar \& Kocaoglu, 2009; Klein, 2009) and has practical implications: to use regression modelling successfully, decision-makers should pre-screen projects and only consider those further that fare similarly with regard to some "make and break" criteria. As a consequence, managerial heuristics should possibly not be regarded as a lower quality substitute for analytical decision methods, but as an enabler.

In many cases, heuristics may furthermore be the only practical approach to front-end screening: regression models may be rejected by decision-makers as obscure mathematical models because they can only be applied with the aid of a computer and require statistical knowledge. Furthermore, companies may lack the data needed to create regression models because they have very limited or no data on the largely unstructured screening activities undertaken in the FFE, no data on the projects that were not selected, and limited information on the project outcomes. And even if relevant historical data exists, regression models are difficult to apply to a new data set because they are based on variations in the criteria and judgments across the data set. Standardized weights are usually calculated by researchers, and application of these weights to a new case requires identification of where that case's criterion values fit in the range of criterion values that were used in the original data set on which the model was formed. In contrast, the three proposed F\&F models are flexible, simple to apply under time limitations, and do not require calculations and historical data.

The differences in performance between these models, however, shows that project screening quality is dependent on the specific F\&F heuristic decision makers use which may differ largely from decision-maker to decision maker. Practitioners report that some decision makers are particularly successful at selecting good projects (Shapin, 2008). It is possible that these individuals use heuristics that perform as well as or even better than the best regression model, which did not outperform the best F\&F heuristic by much. Knowledge of these superior heuristic strategies would not only enable us to explain performance differences between managers, but also to create decision tools that emulate the successful decision behaviour of particularly good decision-makers and make it accessible to less experienced managers. To date, however, the structure of managerial screening heuristics is unknown. F\&F decision making has predominantly been investigated for less complex decision problems that have lower stakes than project screening, such size estimates for cities (Gigerenzer, 2007). And even in these contexts, it is currently unclear, which fast and frugal strategies decision-makers truly employ in a non-laboratory setting. We therefore do not 
know if the F\&F models identified in this paper appropriately describe judgment behaviour in the fuzzy front-end. More research of "real world" front-end screening behaviour is therefore needed. It would help to explain performance differences between decision makers and R\&D groups, would enable us to forecast what decisions are likely to be made, and would help us to optimize front-end funnels. 


\section{References:}

Alam, I. (2003). Commercial innovations from consulting engineering firms: An empirical exploration of a novel source of new product ideas. Journal of Product Innovation Management, 20(4), 300-314.

Albar, F. M., \& Kocaoglu, D. F. (2009). Few or more attributes: Deleting criteria using sensitivity analysis. PICMET. Portland, OR,USA.

Anderson, J. A. (2000). Intuition in managers: Are intuitive managers more effective? Journal of Managerial Psychology, 15(1), 46-57.

Andersson, P., Ekman, M., \& Edman, J. (2003). Forecasting the fast and frugal way: A study of performance and informationprocessing strategies of experts and non-experts when predicting the world cup 2002 in soccer SSE/EFI Working Paper Series in Business Administration, 9.

Astebro, T. B. (2004). Key success factors for technological entrepreneurs' R\&D projects. IEEE Transactions on Engineering Management, 51(3), 314-321.

Astebro, T. B., \& Elhedhli, S. (2006). The effectiveness of simple decision heuristics: A case study of experts' forecasts of the commercial success of early-stage ventures. Management Science, 52(3), 395-409.

Barczak, G., Griffin, A., \& Kahn, K. B. (2009). Perspective: Trends and drivers of success in NPD practices: Results of the 2003 PDMA best practices study. Journal of Product Innovation Management, 26(1), 3-23.

Berretty, P. M., Todd, P. M., \& Blythe, P. W. (1997). Categorization by elimination: A fast and frugal approach to categorization. Nineteenth Annual Conference of the Cognitive Science Society. Mahwah, NJ: Lawrence Erlbaum Associates. 43-48.

Besedes, T., Deck, C., Sarangi, S., \& Shor, M. (2009). Age effects and heuristics in decision making, Louisiana State University, Baton Rouge, LA.

Bröder, A. (2000). Assessing the empirical validity of the 'Take-the-best' heuristic as a model of human probabilistic inference. Journal of Experimental Psychology: Learning, Memory, and Cognition, 26(5), 1332-1346.

Burke, L. A., \& Miller, M. K. (1999). Taking the mystery out of intuitive decision making. Academy al Management Executive, 13(4), 91-99.

Calantone, R. J., diBenedetto, C. A., \& Schmidt, J. B. (1999). Using the analytic hiearchy process in new product screening. Journal of Product Innovation Management, 16(1), 65-76.

Chin, K.-S., Xu, D.-l., Yang, J.-B., \& Lam, J. P.-K. (2008). Group-based ER-AHP system for product project screening. Expert Systems with Applications: An International Journal, 35(4), 1909-1929.

Cook, D., Dixon, P., Duckworth, W., Kaiser, M., Koehle, K., Meeke, W., \& Stephenson, W. (2001). Binary response and logistic regression analysis. Beyond Traditional Statistical Methods. Iowa: Part of the Iowa State University NSF/ILI Project.

Cooper, R. G. (1985). Selecting winning new product projects: Using the NewProd system. Journal of Product Innovation Management, 2(1), 34-44.

Cooper, R. G. (1997). Fixing the fuzzy front end of the new product process: Building the business case. CMA Magazine, 71(8), 2123.

Cooper, R. G. (1999). From experience: The invisible success factors in product innovation. Journal of Product Innovation Management, 16(2), 115-133. 
Cooper, R. G., \& Kleinschmidt, E. J. (1986). An investigation into the new product process: Steps, deficiencies, and impact. Journal of Product Innovation Management, 3(2), 71-85.

Cooper, R. G., \& Kleinschmidt, E. J. (1993). Screening new products for potential winners. Long Range Planning, 26(6), 74-81.

Crawford, M., \& di Benedetto, A. (2007). New products management (Ninth ed.). Cambridge, MA: McGraw Hill.

Daellenbach, U. S., McCarthy, A. M., \& Schoenecker, T. S. (1999). Commitment to Innovation: The Impact of Top Management Team Characteristics. R\&D Management, 29(3), 199-208.

Dhami, M. K., \& Ayton, P. (2001). Bailing and jailing the fast and frugal way. Journal of Behavioral Decision Making, 14(2), 141168.

Dhami, M. K., \& Harries, C. (2001). Fast and frugal versus regression models of human judgment. Thinking and reasoning, 7(1), 527.

Eisenhardt, K. M., \& Sull, D. N. (2001). Strategy as simple rules. Harvard Business Review, 79(1), 106-116.

Fasolo, B., McClelland, G. H., \& Todd, P. M. (2007). Escaping the tyranny of choice: When fewer attributes make choice easier. Marketing Theory, 7(1), 13-26.

Field, A. (2005). Discovering statistics using SPSS (Second ed.). Thousand Oaks, CA: Sage Publications, Inc.

Freedman, D. A. (2005). Statistical Models: Theory and Practice. New York, NY: Cambridge University Press.

Garvin, D. A., \& Roberto, M. A. (2001). What you don't know about making decisions. Harvard Business Review.

Gigerenzer, G. (2007). Gut Feeling: The Intelligence of The Unconscious. New York, NY: Penguin Books.

Gigerenzer, G., Czerlinski, J., \& Martignon, L. (2003). How good are fast and frugal heuristics? In T. Gilovich, D. W. Griffin, \& D. Kahneman (Eds.), Heuristics and Biases: The Psychology of Intuitive Judgment. Cambridge, UK: Cambridge University Press, 559581.

Gigerenzer, G., \& Goldstein, D. G. (1996). Reasoning the fast and frugal way: Models of bounded rationality. Psychological Review, 103(4), 650-66.

Gladwell, M. (2005). Blink: The Power of Thinking Without Thinking. New York, NY: Back Bay Books / Little, Brown and Company.

Glöckner, A., \& Betsch, T. (2008). Multiple-reason decision making based on automatic processing. Bonn, Germany: MPI Collective Goods Preprint.

Goldstein, D. G., \& Gigerenzer, G. (2002). Models of ecological rationality: The recognition heuristic. Psychological Review, 109(1), 75-90.

Griffin, A. (1997). PDMA research on new product development practices: Updating trends and benchmarking best practices. Journal of Product Innovation Management, 14(1), 429-459.

Hammedi, W., van Riel, A. C. R., \& Sasovova, Z. (2011). Antecedents and consequences of reflexivity in new product idea screening. Journal of Product Innovation Management, 28(5), 662-679.

Jetter, A. J. M. (2005). Product planning in fuzzy front end Wiesbaden: Deutscher Universitätsverlag.

Khatri, N., \& Alvin, H. (2000). The role of intuition in strategic decision making. Human Relations, 53(1), 57-86. 
Klein, G. (2003). The Power of Intuition: How to Use Your Gut Feelings to Make Better Decisions at Work (First edition ed.). New York, NY: Doubleday Random House, Inc.

Klein, G. (2009). Streetlights and Shadows: Searching for the Keys to Adaptive Decision Making. Cambridge, MA: The MIT Press.

Koen, P., Ajamian, G., \& Boyce, S. (2002). Fuzzy front end: Effective methods, tools and techniques. In P. Belliveau, A. Griffin, \& S. Somermeyer (Eds.), The PDMA Tool Book for New Product Development. New York, NY: John Wiley \& Sons, 5-35.

Laurent, R.-A. (2006). Elimination by aspect and probabilistic choice, Paris School of Economics, New York, NY.

Lin, C.-T., \& Chen, C.-T. (2004). New product go/no-go evaluation at the front end: a fuzzy linguistic approach. IEEE Transactions on Engineering Management, 51(2), 197-207.

Lockett, G. (1986). Modeling a research portfolio using AHP: A group decision process. R\&D Management, 16(2), $151-160$.

March, J. G. (1994). A Primer on Decision Making: How Decisions Happen (1st ed.). New York, NY: Free Press.

Montoya-Weiss, M. M., \& O'Driscoll, T. M. (2000). From experience: Applying performance support technology in the fuzzy front end. Journal of Product Innovation Management, 17(2), 143-161.

Murphy, S. A., \& Kumar, V. (1997). The front end of new product development: A Canadian survey. R\&D Management, 27(1), 516.

Newell, B. R., Weston, N. J., \& Shanks, D. R. (2003). Empirical tests of a fast and frugal heuristics: Not everyone "takes the best". Organizational Behavior and Human Decision Processes, 91(1), 82-96.

Nobelius, D., \& Trygg, L. (2002). Stop chasing the front end process - Management of early phases in product development projects. International Journal of Project Management, 20(5), 331-340.

Payne, J. W., Bettman, J. R., \& Johnson, E. J. (1993). The Adaptive Decision Maker. New York, NY: Cambridge University Press.

Payne, J. W., James R. Bettman, \& Johnson, E. J. (1988). Adaptive strategy selection in decision making. Journal of Experimental Psychology: Learning, Memory, and Cognition, 14(3), 534-552.

Perkins, D. N., \& Salmon, G. (1989). Are cognitive skills context-bounded? Educational Research, 18(1), 16-25.

Perry, B. E. (2008). Fast and frugal conflict early warning in Sub-Saharan Africa: The role of intelligence analysis, Erie, Pennsylvania.

Reimer, T., \& Rieskamp, J. (2007). Fast and frugal heuristics. In R. F. Baumeister, \& K. D. Vohs (Eds.), Encyclopedia of Social Psychology. Thousand Oaks, CA: Sage Publications, Inc., 346-348.

Reinertsen, D. G. (1999). Taking the fuzziness out of the fuzzy front end. Research Technology Management, 42(6), 25-31.

Rieskamp, J., \& Hoffrage, U. (1999). When do people use simple heuristics, and how can we tell? In G. Gigerenzer, \& P. M. Todd (Eds.), Simple Heuristics That Make Us Smart. Oxford: Oxford University Press.

Sauter, V. L. (1999). Intuitive decision making. Communication of the ACM, 42(6), 109-115.

Scheibehenne, B., Miesler, L., \& Todd, P. M. (2007). Fast and frugal food choices: Uncovering individual decision heuristics. Appetite, 49(3), 578-589.

Shapin, S. (2008). The Scientific Life: A Modern History of Late Modern Vocation. Chicago, IL: The University of Chicago Press.

Simon, H. A., \& Newell, A. (1958). Heuristic problem solving: The next advance in operations research. Operations Research, 6(1), $1-10$. 
Slegers, D. W., Brake, G. L., \& Doherty, M. E. (2000). Probabilistic mental models with continuous predictors. Organizational Behavior and Human Decision Processes, 81(1), 98-114.

Smith, G. F. (2003). Beyond critical thinking and decision making: Teaching business students how to think. Journal of Management Education, 27(1), 24-51.

Smith, P. G., \& Reinertsen, D. G. (1991). Developing Products in Half the Time. New York, NY: Van Nostrand Reinhold.

Snook, B., Dhami, M. K., \& Kavanagh, J. M. (2010). Simply criminal: Predicting burglars' occupancy decisions with a simple heuristic. Law and Human Behavior, 35(4), 316-326.

Stevens, G. A., \& Burley, J. (1997). 3,000 raw ideas = 1 commercial success! Research Technology Management, 40(3), $16-27$.

Sykes, A. O. (1993). An introduction to regression analysis. Chicago Working Paper in Law and Economic. Chicago, IL: University of Chicago, The Law School.

Taylor, J. (2009). Introduction to Applied Statistics- Multiple Linear Regression. Stanford, CA: Department of Statistics, Stanford University.

Tversky, A. (1972). Elimination by aspect: A theory of choice. Psychological Review, 79(4), 281-299.

van Riel, A. C. R., Semeijn, J., Hammedi, W., \& Henseler, J. (2011). Technology-based service proposal screening and decisionmaking effectiveness. Management Decision, 49(5), 762-783. 


\section{Appendix}

Table A1 contains the illustrative data set used to test the three Fast and Frugal Heuristics: Take The Best (TTB), Tallying, and Elimination by Aspect (EBA)

Explanation:

- $\quad$ Criteria Value: 4: excellent, 3: good, 2: fair, 1: poor, 0: not enough information available

- $\quad$ Project Outcome Value: $1=$ project is successful, 2= project is not successful

- $\quad$ Project Decision Value: $1=$ reject, $2=$ accept, $3=$ postpone decision until more information becomes available

\begin{tabular}{|c|c|c|c|c|c|c|c|c|c|c|c|c|}
\hline \multirow[b]{2}{*}{ Project \# } & \multicolumn{7}{|c|}{ Decision Criteria } & \multirow{2}{*}{$\begin{array}{l}\text { Project } \\
\text { Outcome }\end{array}$} & \multicolumn{4}{|c|}{ Project Decision, based on Heuristics } \\
\hline & Profitability & Risk & Superiority & $\begin{array}{c}\text { Tech. } \\
\text { Opportunity }\end{array}$ & Market & $\begin{array}{c}\text { Payback } \\
\text { period }\end{array}$ & Protection & & Tтв & $\begin{array}{l}\text { Tallying } \\
\text { Counter }\end{array}$ & Tallying & EBA \\
\hline Project 1 & 3 & 1 & 0 & 1 & 2 & 2 & 3 & 1 & 2 & 0 & 1 & 1 \\
\hline Project 2 & 2 & 1 & 3 & 4 & 0 & 2 & 0 & 1 & 2 & 2 & 2 & 2 \\
\hline Project 3 & 2 & 2 & 2 & 3 & 2 & 1 & 3 & 1 & 2 & 1 & 2 & 1 \\
\hline Project 4 & 2 & 2 & 2 & 3 & 2 & 3 & 3 & 1 & 2 & 3 & 2 & 1 \\
\hline Project 5 & 0 & 3 & 0 & 3 & 1 & 2 & 1 & 1 & 2 & -2 & 1 & 1 \\
\hline Project 6 & 3 & 2 & 1 & 3 & 1 & 2 & 2 & 1 & 2 & 0 & 1 & 2 \\
\hline Project 7 & 2 & 1 & 4 & 2 & 4 & 2 & 4 & 1 & 2 & 5 & 2 & 2 \\
\hline Project 8 & 3 & 1 & 3 & 1 & 3 & 2 & 1 & 1 & 2 & 0 & 1 & 1 \\
\hline Project 9 & 1 & 2 & 2 & 3 & 1 & 1 & 0 & 1 & 1 & -2 & 1 & 3 \\
\hline Project 10 & 1 & 1 & 2 & 0 & 1 & 3 & 1 & 1 & 1 & -3 & 1 & 1 \\
\hline Project 11 & 1 & 3 & 1 & 2 & 1 & 3 & 1 & 1 & 1 & -2 & 1 & 1 \\
\hline Project 12 & 1 & 1 & 1 & 4 & 1 & 2 & 3 & 1 & 1 & -1 & 1 & 1 \\
\hline Project 13 & 2 & 1 & 0 & 2 & 2 & 1 & 2 & 1 & 2 & -2 & 1 & 1 \\
\hline Project 14 & 2 & 3 & 3 & 2 & 2 & 3 & 3 & 1 & 2 & 4 & 2 & 2 \\
\hline Project 15 & 2 & 3 & 1 & 2 & 2 & 0 & 2 & 1 & 2 & 0 & 1 & 3 \\
\hline Project 16 & 2 & 2 & 1 & 2 & 2 & 2 & 2 & 1 & 2 & -1 & 1 & 1 \\
\hline Project 17 & 1 & 1 & 1 & 4 & 0 & 2 & 1 & 1 & 1 & -2 & 1 & 1 \\
\hline Project 18 & 2 & 0 & 2 & 2 & 1 & 1 & 1 & 1 & 2 & -3 & 1 & 1 \\
\hline Project 19 & 3 & 2 & 3 & 1 & 3 & 3 & 0 & 1 & 2 & 3 & 2 & 2 \\
\hline Project 20 & 2 & 2 & 3 & 1 & 3 & 2 & 1 & 1 & 2 & 0 & 1 & 3 \\
\hline Project 21 & 1 & 2 & 1 & 1 & 1 & 1 & 3 & 1 & 1 & -4 & 1 & 1 \\
\hline Project 22 & 1 & 1 & 1 & 1 & 1 & 2 & 3 & 1 & 1 & -4 & 1 & 1 \\
\hline Project 23 & 1 & 3 & 2 & 2 & 1 & 3 & 0 & 1 & 1 & 0 & 1 & 3 \\
\hline Project 24 & 1 & 1 & 0 & 1 & 1 & 1 & 2 & 1 & 1 & -5 & 1 & 1 \\
\hline Project 25 & 2 & 1 & 3 & 1 & 2 & 2 & 2 & 1 & 2 & -1 & 1 & 1 \\
\hline Project 26 & 2 & 2 & 3 & 3 & 2 & 3 & 2 & 1 & 2 & 3 & 2 & 2 \\
\hline Project 27 & 2 & 2 & 1 & 1 & 2 & 1 & 1 & 1 & 2 & -4 & 1 & 1 \\
\hline
\end{tabular}

Table Continued 


\begin{tabular}{|c|c|c|c|c|c|c|c|c|c|c|c|c|}
\hline Project 28 & 2 & 3 & 3 & 2 & 2 & 2 & 1 & 1 & 2 & 1 & 2 & 2 \\
\hline Project 29 & 2 & 3 & 0 & 1 & 3 & 0 & 1 & 1 & 2 & 0 & 1 & 1 \\
\hline Project 30 & 0 & 3 & 2 & 2 & 2 & 1 & 0 & 1 & 2 & 0 & 1 & 3 \\
\hline Project 31 & 1 & 2 & 2 & 2 & 2 & 2 & 0 & 1 & 1 & -1 & 1 & 1 \\
\hline Project 32 & 4 & 1 & 4 & 1 & 4 & 1 & 4 & 2 & 2 & 5 & 2 & 1 \\
\hline Project 33 & 3 & 3 & 2 & 2 & 2 & 1 & 2 & 2 & 2 & 1 & 2 & 2 \\
\hline Project 34 & 3 & 3 & 2 & 2 & 3 & 2 & 3 & 2 & 2 & 4 & 2 & 2 \\
\hline Project 35 & 3 & 2 & 3 & 2 & 2 & 3 & 3 & 2 & 2 & 4 & 2 & 2 \\
\hline Project 36 & 2 & 1 & 3 & & 3 & 2 & 3 & 2 & 2 & 4 & 2 & 1 \\
\hline Project 37 & 2 & 2 & 2 & 2 & 2 & 0 & 3 & 2 & 2 & 1 & 2 & 1 \\
\hline Project 38 & 2 & 3 & 0 & 3 & 3 & 1 & 1 & 2 & 2 & 1 & 2 & 2 \\
\hline Project 39 & 0 & 0 & 3 & 1 & 2 & 0 & 0 & 2 & 2 & 0 & 1 & 1 \\
\hline Project 40 & 3 & 1 & 4 & 1 & 3 & 3 & 1 & 2 & 2 & 2 & 2 & 1 \\
\hline Project 41 & 3 & 2 & 2 & 3 & 2 & 3 & 2 & 2 & 2 & 3 & 2 & 2 \\
\hline Project 42 & 3 & 2 & 2 & 3 & 1 & 3 & 1 & 2 & 2 & 1 & 2 & 2 \\
\hline Project 43 & 2 & 0 & 3 & 3 & 3 & 3 & 2 & 2 & 2 & 4 & 2 & 3 \\
\hline Project 44 & 1 & 2 & 0 & 2 & 1 & 0 & 2 & 2 & 1 & -2 & 1 & 1 \\
\hline Project 45 & 3 & 3 & 4 & 2 & 1 & 2 & 0 & 2 & 2 & 3 & 2 & 2 \\
\hline Project 46 & 3 & 2 & 2 & 3 & 2 & 2 & 2 & 2 & 2 & 2 & 2 & 2 \\
\hline Project 47 & 4 & 2 & 3 & 4 & 4 & 3 & 1 & 2 & 2 & 7 & 2 & 2 \\
\hline Project 48 & 1 & 2 & 2 & 4 & 1 & 1 & 1 & 2 & 1 & -2 & 1 & 3 \\
\hline Project 49 & 3 & 3 & 2 & 3 & 1 & 3 & 2 & 2 & 2 & 3 & 2 & 2 \\
\hline Project 50 & 3 & 2 & 2 & 0 & 0 & 2 & 1 & 2 & 2 & 0 & 1 & 3 \\
\hline Project 51 & 2 & 3 & 4 & 4 & 3 & 2 & 2 & 2 & 2 & 6 & 2 & 2 \\
\hline Project 52 & 3 & 3 & 2 & 3 & 4 & 1 & 2 & 2 & 2 & 4 & 2 & 2 \\
\hline
\end{tabular}


